\author{
Marquette University \\ e-Publications@Marquette
}

3-2002

\title{
Real Money Balances and Production Efficiency: A Panel-Data Stochastic Production Frontier Study
}

Farrokh Nourzad

Marquette University, farrokh.nourzad@marquette.edu

Follow this and additional works at: https://epublications.marquette.edu/econ_fac

Part of the Economics Commons

\section{Recommended Citation}

Nourzad, Farrokh, "Real Money Balances and Production Efficiency: A Panel-Data Stochastic Production Frontier Study" (2002). Economics Faculty Research and Publications. 104.

https://epublications.marquette.edu/econ_fac/104 
Marquette University

e-Publications@Marquette

\title{
Economics Faculty Research and Publications/College of Business Administration
}

This paper is NOT THE PUBLISHED VERSION; but the author's final, peer-reviewed manuscript. The published version may be accessed by following the link in the citation below.

Journal of Macroeconomics, Vol. 24, No. 1 (March 2002): 125-134. DOl. This article is (C) Elsevier and permission has been granted for this version to appear in e-Publications@Marquette. Elsevier does not grant permission for this article to be further copied/distributed or hosted elsewhere without the express permission from Elsevier.

\section{Real Money Balances and Production Efficiency: A Panel-Data Stochastic Production Frontier Study}

Farrokh Nourzad

Department of Economics, Marquette University, Milwaukee, WI

\begin{abstract}
This paper examines the effect of four alternative measures of real money balances on production efficiency using annual panels of 10 developed and 10 developing countries. Using maximum likelihood, separate stochastic production frontiers are estimated, along with the parameters of an equation relating technical inefficiency to real money balances. The results for the sample of developed economies indicate that increases in real simple-sum M1, simple-sum M2, Divisia M1, and Divisia M2 enhance efficiency in the production sector. On the other hand, in the sample of developing nations, there is no evidence that real money balances reduce technical inefficiency.
\end{abstract}




\section{Keywords}

Production frontier, Technical efficiency, Divisia money

\section{Introduction}

A controversial issue in monetary economics that has lasted for more than thirty years is whether real money balances can be considered a productive input. Those who favor including money balances in an economy-wide production function argue that money facilitates transactions, including the acquisition of capital and labor. As Sinai and Stokes (1972, p. 290) put it "in a monetary economy, productive efficiency may increase as labor and capital services, released from the special tasks required in a barter economy, are used in production".

There exists a large body of empirical literature on the productivity effect of real money balances. Sinai and Stokes (1972) were the first to directly test the proposition that real money balances constitute an input in the production process. Since then, many aspects of the inclusion of money in an aggregate production function have been studied. These include the differential productivity effect of money in developing and developed countries (Chowdhury and Liu, 1995; Khan and Ahmad, 1985; Paul and Bhattacharyay, 1986), the proper functional form of the production function (Hsing, 1990), and the role of anticipated and unanticipated money (Beladi and Samanta, 1988) to name but a few.

The empirical money-in-the-production-function literature has been criticized on the grounds that there is no theoretical foundation for treating money as productive input (Davidson, 1979; Fischer, 1974; Nguyen, 1986). A synthesis of the two opposing views is that money balances should not be treated as a productive input that increases output or productivity directly but rather as a factor that increases the overall efficiency in the economy. Even Sinai and Stokes, who include real money balances in an aggregate production function, state that "the rationale for including money balances in the production function relates, in part, to the increased 'economic efficiency' of a monetary economy compared with a barter economy". This line of reasoning is extended by Moroney (1972) and Saving (1972) among others. To my knowledge, the recent empirical study by DeLorme et al. (1995) is the only work that approaches the role of real money balances in the production process from this angle.

In this paper, I follow DeLorme et al. (1995) and examine the effect of real money balances in enhancing technical efficiency. However, my work differs from theirs in the following ways. First, while they use annual data for the US alone, I use annual panels of 10 developed and 10 developing countries. Second, and most important, whereas they use a two-stage approach to estimate the effect of real money balances on technical inefficiency, I use the single-stage procedure due to Battese and Coelli (1995) to estimate jointly the parameters of the production function and the effect of real money balances. As Coelli et al. (1998, p. 207) note, "a significant problem with [the] two-stage approach ... [is that in] the first stage, the inefficiency effects are assumed to be independently and identically distributed ... in order to predict the values of the technical inefficiency effects. However, in the second stage, the predicted inefficiency effects are assumed to be a function of a number of firm-specific factors, which implies that they are not independently distributed, unless the coefficients of the factors are simultaneously equal to zero". The two-stage approach is likely to generate estimates that are less efficient than those obtained from the single-stage procedure (Coelli, 1996).

Using the Coelli-Battese single-stage method, I estimate a Cobb-Douglas production frontier and use the results to examine the effect of alternative monetary aggregates on technical efficiency over time and space. The central hypothesis tested in this paper is whether real money balances are statistically significantly correlated to the estimated production efficiencies. The estimation results indicate that real money balances enhance technical efficiency in industrialized countries but not in developing economies. 
Section 2 outlines the econometric approach used in this paper, while Section 3 presents and discusses the estimation results. The paper closes with Section 4, which contains a summary of this work.

\section{Econometric methodology}

The standard stochastic production frontier (SPF) can be presented in the context of the following log-linear Cobb-Douglas functional form (Aigner et al., 1977; Meeusen and van den Broeck, 1977),

(1) $y_{i}=x_{i} \beta^{\prime}+\varepsilon_{i}, i=1,2, \ldots, N$,

where $y_{i}$ is the logarithm of output of firm (country or industry) $i$; $x_{i}$ is a $1 \times(k+1)$ row vector whose first element is 1 and the remaining elements represent the logarithms of the $k$ inputs used by the ith firm; and $B^{\prime}$ is a $(k+1) \times 1$ column vector of unknown parameters. The random error term, $\varepsilon_{i}$, is the difference of two independent random variables: a classical error term, $v_{i}$, and a non-negative random variable, $u_{i}$, capturing technical inefficiencies in firm $i$,

(2) $\varepsilon_{i}=v_{i}-u_{i}$,

where the error variance is given by

(3) $\sigma_{\varepsilon}^{2}=\sigma^{2}{ }_{v}+\sigma^{2}$.

While $v_{i}$ is typically assumed to be iid. $n\left(0, \sigma_{v}^{2}\right)$, the choice of a distribution for $u_{i}$ is arbitrary. In practice different researchers have used a number of alternative distributions, including the truncated normal, half normal, gamma, and exponential distributions.

In this context, the technical efficiency of the ith firm, $\mathrm{TE}_{i}$, is the ratio of observed output of firm $i$ divided by its efficient output represented by the estimated production frontier,

(4) $\mathrm{TE}_{\mathrm{i}}=\mathrm{y}_{\mathrm{i}} / \exp \left(\mathrm{x}_{\mathrm{i}} \beta^{\prime}\right)=\exp \left(-\mathrm{u}_{\mathrm{i}}\right)$.

The technical efficiency coefficient in Eq. (4), which is bounded between zero and one, is unobservable because $u_{i}$ is unobservable. Battese and Coelli (1988) show that the best estimator of $\exp \left(-u_{i}\right)$ is its conditional expectation, $E\left[\exp \left(-u_{i}\right) \mid \varepsilon_{i}\right]$.

The above model, which implicitly assumes cross-sectional data, can easily be extended to panel data (Pitt and Lee, 1981). The panel-data version of the model in , is as follows:

(5) $y_{i t}=x_{i t} \beta^{\prime}+\varepsilon_{i t}, i=1,2, \ldots, N ; t=1,2, \ldots, T$,

And

(6) $\varepsilon_{i t}=v_{i t}-u_{i t}$.

Different versions of the panel-data SPF model have been proposed and estimated, ranging from models that assume the production inefficiencies, $u_{i t}$, are $i i d$, to those that assume them to be time invariant, to models in which technical inefficiencies vary over time. ${ }^{1}$ The specification used here is due to Battese and Coelli (1995) in which technical efficiencies are affected by external factor(s) across space and over time. This model consists of , in which the $u_{i t}$ component of the error term in Eq. (6) is assumed to be a non-negative, independently distributed random variable, which is distributed as the truncation at zero of $n\left(\mu_{i t}, \sigma^{2}\right)$ where

(7) $\mu_{\mathrm{it}}=\mathrm{z}_{\mathrm{it}} \delta^{\prime}$. 
Here, $z_{i t}$ is a vector of factors that may have an influence on technical inefficiencies in firm $i$ in period $t$, and $\delta^{\prime}$ is a column vector of unknown parameters that are to be estimated.

Note that neither the basic SPF model in , nor its panel-data version presented above can be estimated using OLS. This is because OLS assumes that $u=0$. As a result the OLS estimate of $B_{0}$ would be biased downwards, those of $B_{1}, b_{2}, \ldots, b_{k}$, would be unbaised, but $\operatorname{SE}(\hat{\beta})$ would be biased. To avoid this, both specifications of the SPF model should be estimated using maximum likelihood. However, if $\gamma=\delta_{0}=\delta_{1}=, \ldots, \delta_{s}=0$, where $\gamma=\sigma^{2} / \sigma_{\varepsilon}^{2}$, there are no technical inefficiencies and Eq. (5) can be estimated by OLS and the resulting parameter estimates will be efficient.

While one can estimate indices of technical efficiency using either a production frontier or a cost frontier, I use the former. I begin with the following Cobb-Douglas production frontier,

(8) $Q_{i t}=\beta_{0}+\beta_{1} L_{i t}+\beta_{2} K_{i t}+\beta_{3} t+\varepsilon_{i t}$,

where $Q, L$, and $K$ denote the natural logarithms of output, labor, and capital stock, respectively, the stochastic error term, $\varepsilon_{i t}$, is as defined in (6), $i$ is the country index, and $t$ is the time index. ${ }^{2}$ I assume the $u_{i t}$ component of $\varepsilon_{i t}$, which represents technical inefficiency, follows the generalized truncated-normal distribution. I specify technical inefficiencies as a function of the natural log of real money balances in country $i$ at time $t$, denoted $m_{i t}$,

(9) $\mu_{\mathrm{it}}=\delta_{0}+\delta_{1} \mathrm{~m}_{\mathrm{it}}$.

I estimate, using maximum likelihood. ${ }^{3}$ This yields point estimates of the parameters of the production function $\left(B_{0}, b_{1}, b_{2}, b_{3}\right)$ as well as estimates of the coefficients of the relation between real money balances and technical inefficiencies, $\left(\delta_{0}, \delta_{1}\right)$. As was indicated earlier, the joint estimation of these two sets of parameters is a major difference between the present study and that by DeLorme et al. (1995). They use a two-step approach in which technical efficiency indicies are estimated first from the basic frontier model in , and then regressed on real money balances in a separate regression equation.

I use annual data for 10 developed and 10 developing countries covering the period from 1981-1990. The countries in the sample, sources of data and other pertinent information are found in the appendix. In order to be consistent with the earlier money-in-the-production-function literature, I use alternatively real M1 and real M2 aggregates for money balances, $m$, in Eq. (9). However, in recognition of the fact that simple-sum M1 and simple-sum M2 are not consistent with neoclassical theory, I also use real Divisia M1 and real Divisia M2 to represent monetary aggregates in Eq. (9). ${ }^{4}$

\section{Results}

Before estimating, jointly using maximum likelihood, I test whether the samples of developed and developing countries can be pooled. ${ }^{5}$ For this purpose, I pooled the two samples and constrained them to have the same intercept and slope coefficients. The resulting likelihood ratio (LR), which has a chi-square distribution with four degrees of freedom, equaled 64.89. This is highly statistically significant, indicating that the two samples cannot be pooled and must be used separately to estimate the model in , .

Table 1 reports the results from the sample of industrialized nations. I begin with the results in the top portion of this table concerning the effects of capital and labor. The estimated coefficients associated with these traditional inputs have the expected positive sign and are statistically significant at the $1 \%$ level across all four equations. Moreover, in no case is the sum of the estimated coefficients on labor and capital significantly different from one, indicating that the pooled aggregate production function exhibits constant returns to scale. 
The results in Table 1 reveal that the estimated coefficient on the trend variable, which captures the rate of disembodied technological change, is positive and highly statistically significant in all four equations.

Table 1. Maximum likelihood estimates of SPF using an annual panel of 10 industrialized countries, 1981-1990 (asymptotic standard errors in parentheses)

\begin{tabular}{|l|l|l|l|l|}
\hline Variables & Simple-sum M1 & Divisia M1 & Simple-sum M2 & Divisia M2 \\
\hline Intercept & 4.3220331 & 5.01792100 & 4.71621650 & 4.76178470 \\
& $(0.31665318)^{\mathrm{a}}$ & $(0.19954076)^{\mathrm{a}}$ & $(0.02039956)^{\mathrm{a}}$ & $(0.23397001)^{\mathrm{a}}$ \\
\hline$L$ & 0.57741090 & 0.63591087 & 0.59231763 & 0.60000247 \\
& $(0.03886576)^{\mathrm{a}}$ & $(0.019010318)^{\mathrm{a}}$ & $(0.0027618)^{\mathrm{a}}$ & $(0.01258762)^{\mathrm{a}}$ \\
\hline$K$ & 0.48097845 & 0.42027813 & 0.45785707 & 0.45144506 \\
& $(0.03578804)^{\mathrm{a}}$ & $(0.01875602)^{\mathrm{a}}$ & $(0.00242660)^{\mathrm{a}}$ & $(0.01150757)^{\mathrm{a}}$ \\
\hline Trend & 0.10095921 & 0.00570276 & 0.0066404459 & 0.00677184 \\
& $(0.00289869)^{\mathrm{a}}$ & $(0.00137731)^{\mathrm{a}}$ & $(0.00144430)^{\mathrm{a}}$ & $(0.00122206)^{\mathrm{a}}$ \\
\hline Intercept & 0.49187273 & 0.83093746 & 1.11736290 & 1.3374346 \\
& $(0.19107688)^{\mathrm{a}}$ & $(0.08366794)^{\mathrm{a}}$ & $(0.43520240)^{\mathrm{a}}$ & $(0.24482650)^{\mathrm{a}}$ \\
\hline Monetary & -0.076864817 & -0.14089963 & -0.22094614 & -0.14006504 \\
aggregate & $(0.03881876)^{\mathrm{b}}$ & $(0.02111857)^{\mathrm{a}}$ & $(0.10075098)^{\mathrm{b}}$ & $(0.02263169)^{\mathrm{a}}$ \\
\hline$\sigma^{2}$ & 0.04669040 & 0.0555555 & 0.1354788 & 0.04495300 \\
\hline$V$ & 0.99999999 & 0.9999999 & 0.9999999 & 0.99900319 \\
\hline LR & $86.011458^{\mathrm{a}}$ & $80.446563^{\mathrm{a}}$ & $86.011458^{\mathrm{a}}$ & $91.267709^{\mathrm{a}}$ \\
\hline LLF & 90.418148 & 87.635701 & 90.418148 & 93.046274 \\
\hline Is natural & & & & \\
\hline
\end{tabular}

$L$ is natural logarithm of number of workers.

$K$ is natural logarithm of stock of capital.

${ }^{a}$ Significant at the $1 \%$ level of a two-tailed test.

${ }^{b}$ Significant at the $5 \%$ level of a two-tailed test.

Next, I test the hypothesis that there are no technical inefficiencies, that is, $\gamma=\delta_{0}=\delta_{1}=0$. The test statistic is a LR which has a mixed chi-square distribution with three degrees of freedom. The results in the lower portion of Table 1 indicate that the LR statistic, which equals 86.01, 80.45, 86.01, and 91.27 for the models with simplesum M1, Divisia M1, simple-sum M2 and Divisia M2, respectively, is highly significant. Moreover, in all cases the variance parameter, $\gamma$, is nearly one (0.999), suggesting that almost all of the variation in the random error term in Eq. (8) is due to technical inefficiencies. ${ }^{6}$

Finally, consider the estimated coefficients on the alternative measures of real money balances in the middle section of Table 1 . These estimates are negative and statistically significant at the $5 \%$ level or better for all four monetary aggregates. However, there are several notable differences regarding the point estimates of the coefficients on the various monetary aggregates. First, while the effect of simple-sum $M 2$ is nearly three times that of simple-sum M1, the estimated coefficients associated with Divisia M1 and Divisia M2 are virtually equal. Second, the latter two estimates have smaller standard errors than the former. All in all, though, the model that uses Divisia M2 appears to be the preferred model on statistical grounds as it has the smallest standard error of estimate $(\sigma=0.212)$ and the largest value of the log likelihood function (93.05).

To summarize, the results from the sample of industrialized nations suggest that an increase in any of the four alternative measures of real money balances would reduce technical inefficiencies in production. This is consistent with the view that real money balances improve the efficiency with which the production sector operates. It is also consistent with the findings of DeLorme et al. (1995) for the US. Thus, these results reconcile economic theory and empirical findings in monetary economics as suggested by DeLorme et al. 
The next step in this exercise is to estimate an SPF model using the panel of 10 developing nations. The maximum likelihood estimates and the associated summary statistics are found in Table 2 . As far as the effect of the traditional inputs of labor and capital are concerned, with one exception the results are generally consistent with those of the developed nations. The only exception is the fact that none of the estimated production functions exhibits constant returns to scale. Another difference between the two sets of results is the fact that the estimated coefficients on the trend variable for the equations containing simple-sum and Divisia M1 are barely significant.

Table 2. Maximum likelihood estimates of SPF using an annual panel of 10 developing countries 1981-1990 (asymptotic standard errors in parentheses)

\begin{tabular}{|l|l|l|l|l|}
\hline Variables & Simple-sum M1 & Divisia M1 & Simple-sum M2 & Divisia M2 \\
\hline Intercept & 8.2391506 & 8.17226347 & 7.99569450 & 8.13926600 \\
& $(0.99885600)^{\mathrm{a}}$ & $(0.70240232)^{\mathrm{a}}$ & $(0.38002700)^{\mathrm{a}}$ & $(0.35554610)^{\mathrm{a}}$ \\
\hline$L$ & 0.47459622 & 0.49872504 & 0.44877981 & 0.47920333 \\
& $(0.02688371)^{\mathrm{a}}$ & $(0.05797175)^{\mathrm{a}}$ & $(0.02402185)^{\mathrm{a}}$ & $(0.02419953)^{\mathrm{a}}$ \\
\hline$K$ & 0.36447374 & 0.35494500 & 0.39370217 & 0.36442784 \\
& $(0.04720496)^{\mathrm{a}}$ & $(0.03204984)^{\mathrm{a}}$ & $(0.02440216)^{\mathrm{a}}$ & $(0.02516743)^{\mathrm{a}}$ \\
\hline Trend & 0.021263176 & 0.02919117 & 0.01778776 & $0.02705178(0.00808832)^{\mathrm{a}}$ \\
& $(0.01230551)^{\mathrm{b}}$ & $(0.01763069)^{\mathrm{b}}$ & $(0.00785401)^{\mathrm{c}}$ & \\
\hline Intercept & -0.16432108 & -0.54610468 & -0.43300066 & -2.2791634 \\
& $(0.40103441)$ & $(0.68215064)$ & $(0.71072909)$ & $(1.31228460)^{\mathrm{b}}$ \\
\hline Monetary & 0.071495944 & 0.07107123 & 0.04592952 & $0.07754826(0.09050557)$ \\
aggregate & $(0.06101526)$ & $(0.06171120)$ & $(0.04538229)$ & \\
\hline$\sigma^{2}$ & 0.06267396 & 0.07793562 & 0.06623118 & 0.06614000 \\
\hline$V$ & 0.67030226 & 0.79033946 & 0.66786964 & 0.62097108 \\
\hline LR & $7.2557496^{\mathrm{b}}$ & $6.1872275^{\mathrm{b}}$ & $7.7937900^{\mathrm{b}}$ & $8.9886684^{\mathrm{c}}$ \\
\hline LLF & 17.114130 & 16.549869 & 14.875945 & 17.980590 \\
\hline Is natural & & & \\
\hline
\end{tabular}

$L$ is natural logarithm of number of workers.

$K$ is natural logarithm of stock of capital.

aSignificant at the $1 \%$ level of a two-tailed test.

${ }^{\text {bS }}$ Significant at the $10 \%$ level of a two-tailed test.

'Significant at the $5 \%$ level of a two-tailed test.

In contrast, the results concerning the effect of alternative measures of real money balances in the middle section of Table 2 differ from those of the developed nations. The hypothesis that there is no technical inefficiency can be rejected only at low levels of confidence (the $90 \%$ percent level in three of the four cases). Moreover, the estimated values of the variance parameter, $v$, are much smaller than those of the developed nations, ranging from a low of 0.62 to a high of 0.79 . Thus, it appears that technical production inefficiencies are only partially responsible for variation in the error term in Eq. (8).

The most important difference between the results in Table 2 and those in Table 1 is the fact that the estimated coefficients on the four monetary aggregates are positive, although none is statistically significant at conventional levels. This suggests that money does not help to improve production efficiency in developing countries. A possible explanation for this result is that in these countries financial institutions are not able to reduce the cost of acquiring information to help inputs to move to their most efficient uses. Reduction of such costs are particularly important in those instances where the acquisition of information concerning the most efficient production process involves a substantial fixed cost (Levine, 1997). 
The above finding regarding the differential efficiency effect of money balances in developed and developing countries contradicts the notion that money is more productive in developing countries, a hypothesis that has been tested by Khan and Ahmad (1985), Chowdhury and Liu (1995), and Paul and Bhattacharyay (1986), among others. Using a conventional money-in-the-production-function approach and a simultaneous-equations model, Khan and Ahmad (1985, p. 338) find real M1 and real M2 balances to be "an important factor of production in the large-scale manufacturing sector of Pakistan". On the other hand, Paul and Bhattacharyay (1986, p. 207), who also use the conventional production-function approach to estimate the output elasticities of real M1 and real monetary base for India and Pakistan, conclude that their "evidence is inconsistent with the view that money is more productive in developing countries". This is consistent with the result reported by Chowdhury and Liu (1995, p. 120) who use a similar approach with a sample of 20 countries in various stages of development and find that "money does not play a more productive role in a developing economy relative to a developed economy".

\section{Summary}

This paper examined the effect of four alternative measures of real monetary balances on productive efficiency with two separate annual panels of 10 developed and 10 developing countries over the period from 1981-1990. Using maximum likelihood, separate stochastic Cobb-Douglas production frontiers were estimated jointly with the effect of real money balances on technical inefficiency indices. For the sample of industrialized countries, the results indicate that real monetary aggregates defined as simple-sum M1, simple-sum M2, Divisia M1 and Divisia M2 have a statistically significant negative effect on technical inefficiency, suggesting that increases in these monetary aggregates enhance efficiency in the production sector. On the other hand, in the sample of developing nations, there is no evidence that real money balances reduce technical inefficiencies.

\section{Acknowledgements}

The author wishes to thank two anonymous referees of the Journal for their many valuable suggestions and comments on an earlier version of this paper. I am solely responsible for any remaining errors. This research is partially funded by a Marquette University College of Business Administration Faculty Grant from the Miles Fund.

\section{Countries in the sample and data sources}

The two panels consists of the following 10 developed and 10 developing countries:

\begin{tabular}{|l|l|}
\hline Australia & Indonesia \\
\hline Canada & Malaysia \\
\hline France & Mauritius \\
\hline Germany & Morocco \\
\hline Ireland & Nigeria \\
\hline Japan & Philippines \\
\hline Netherlands & Singapore \\
\hline Switzerland & South Korea \\
\hline UK & Sri Lanka \\
\hline USA & Thailand \\
\hline
\end{tabular}

- The data used to quantify the arguments of the production function in Eq. (8) are taken from Easterly and Levine (1999). 
- The data on simple-sum M1 and simple-sum M2 for Indonesia, Malaysia, Singapore, South Korea, Sri Lanka, and Thailand are taken from Habibullah (1999). For all other countries these series are taken from the International Monetary Fund International Financial Statistics CD ROM.

- Divisia M1 and Divisia M2 for Indonesia, Malaysia, Singapore, South Korea, Sri Lanka, and Thailand are taken from Habibullah (1999).

- Divisia M1 and Divisia M2 for Japan and Divisia M1 for the Netherlands are taken from the International Divisia Database, the Ole Miss Project on Monetary Economics, Banking Studies, Index Numbers and Computation, www.bus.olemiss.edu/divisia/.

- The M1 and M2 Monetary Services Index (Divisia) for the US are from Anderson et al. (1997) available from the Federal Reserve Bank of St. Louis web site at www.stls.frb.org/research/msi/.

- Divisia M1 and Divisia M2 for all other countries in the sample are constructed by the author using the method developed by Barnett (1980). The data on the various components of M1 and M2 and the required interest rates are taken from the IMF International Financial Statistics CD ROM.

- The Consumer Price Index used to express the monetary aggregates in real terms is taken from the UN Global Development Finance and World Development Indicators.

\section{References}

Aigner et al., 1977. D.J. Aigner, C.A.K. Lovell, P. Schmidt. Formulation and estimation of stochastic frontier production function models. Journal of Econometrics, 6 (1977), pp. 21-37

Anderson et al., 1997. R.G. Anderson, B.E. Jones, T.D. Nesmith. Building new monetary services indexes: concepts, data and methods. Review, Federal Reserve Bank of St. Louis, 79 (1997), pp. 53-82

Barnett, 1980. W.A. Barnett. Economic monetary aggregates: an application of index number and aggregation theory. Journal of Econometrics, 14 (1980), pp. 11-48

Battese and Coelli, 1995. G.E. Battese, T.J. Coelli. A model for technical inefficiency effects in a stochastic production frontier for panel data. Empirical Economics, 20 (1995), pp. 325-332

Battese and Coelli, 1988. G.E. Battese, T.J. Coelli. Prediction of firm-level technical efficiencies with a generalized frontier production function and panel data. Journal of Econometrics, 38 (1988), pp. 387399

Beladi and Samanta, 1988. H. Beladi, S.K. Samanta. Unanticipated monetary policy and real output: some evidence from the UK. Economy. Applied Economics, 20 (1998), pp. 721-730

Chowdhury and Liu, 1995. A.R. Chowdhury, Y. Liu. Is money more productive in a developing economy? Applied Economics Letters, 2 (1995), pp. 118-121

Coelli, 1996. Coelli, Tim J., 1996. A Guide to FRONTIER Version 4.1: A Computer Program for Stochastic Production and Cost Function Estimation. Centre for Efficiency and Productivity Analysis, University of New England, Armidale, NSW, Australia, Working paper 96/07

Coelli et al., 1998. T.J. Coelli, D.S.P. Rao, G.E. Battese. An Introduction to Efficiency and Productivity Analysis, Kluwer Academic Publishers, Boston (1998)

Davidson, 1979. P. Davidson. Money as a factor of production: ultimate neoclassical theory or Keynesian insight. a rejoinder. Journal of Post-Keynesian Economics, 2 (1979-1980), pp. 280-282

DeLorme et al., 1995. C.D. DeLorme, H.G. Thompson, R.S. Warren. Money and production: a stochastic frontier approach. Journal of Productivity Analysis, 6 (1995), pp. 333-342

Easterly and Levine, 1999. Easterly, W., Ross, L., 1999. It's Not Factor Accumulation: Stylized Facts and Growth Models. World Bank and University of Minnesota, Mimeo

Fischer, 1974. S. Fischer. Money and the production function. Economic Inquiry, 12 (1974), pp. 517-533

Habibullah, 1999. M.S. Habibullah. Divisia Monetary Aggregates and Economic Activities in Asian Developing Economies, Ashgate, Brookfield (1999) 
Hsing, 1990. Y. Hsing. International evidence on the non-neutrality of money. Journal of Macroeconomics, 12 (1990), pp. 467-474

Khan and Ahmad, 1985. A.K. Khan, A. Mushtaq. Real money balances in the production function of a developing country. Review of Economics and Statistics, 67 (1985), pp. 336-340

Levine, 1997. R. Levine. Financial development and economic growth: views and agenda. Journal of Economic Literature, 35 (1997), pp. 688-726

Meeusen and van den Broeck, 1977. W. Meeusen, J. van den Broeck. Efficiency estimation from Cobb-Douglas production functions with composed error. International Economic Review, 18 (1977), pp. 435-444

Moroney, 1972. J.R. Moroney. The current state of money and production theory. American Economic Review, 62 (1972), pp. 335-343

Nguyen, 1986. H.V. Nguyen. Money in the aggregate production function: reexamination and further evidence. Journal of Money, Credit and Banking, 18 (1986), pp. 141-151

Paul and Bhattacharyay, 1986. T.M. Paul, B.N. Bhattacharyay. Can money matter in a developing economy? Journal of Monetary Economics, 18 (1986), pp. 205-207

Pitt and Lee, 1981. M.M. Pitt, L.-F. Lee. Measurement and sources of technical inefficiency in the Indonesian weaving industry. Journal of Development Economics, 9 (1981), pp. 43-64

Saving, 1972. T.R. Saving. Transactions costs and the demand for money. Journal of Money, Credit and Banking, 4 (1972), pp. 245-259

Sinai and Stokes, 1972. A. Sinai, H.H. Stokes. Real money balances: an omitted variable in the production function. Review of Economics and Statistics, 54 (1972), pp. 290-296

${ }^{1}$ For more on different specifications of the panel SPF model see Coelli et al. (1998, pp. 202-204).

${ }^{2}$ It is customary in applied production analysis to include a trend variable in the production function as a proxy for disembodied technological change.

${ }^{3}$ I use the FRONTIER software, version 4.1 by Coelli (1996). One can also use LIMDEP to estimate SPFs.

${ }^{4}$ This fact was pointed out by an anonymous referee.

${ }^{5}$ This is necessary given structural and institutional differences between the two sets of countries. For example, the level of monetary aggregation is likely to be different in developing countries relative to the developed nations. In other words, different assets serve as media of exchange in the two sets of countries.

${ }^{6} \mathrm{An}$ implication of this is that, for the sample of industrialized countries, the SPF model is not much different from the deterministic frontier model. 